\title{
A Bird's-Eye View from the Field-How a Police Experts Network Can Be an Important Link in Facilitating Sustainable Community-Oriented Policing in Post-Conflict Contexts
}

\author{
Jaishankar Ganapathy $^{1, \star}$, Tor Damkaas ${ }^{1}$ and Alf Halvar Naesje ${ }^{2}$ \\ ${ }^{1}$ Norwegian Police University College, Oslo, Norway \\ 2 The Centre Party, Hedmark and Oppland, Norway \\ Corresponding author: Jaishankar.Ganapathy@phs.no; Phone: +47 23199812
}

Submitted: 24 May 2018 | In revised form: 22 September 2020 | Accepted: 5 March 2021 |

Published: 20 May 2021

\begin{abstract}
Police reform in post-conflict societies is increasingly important in international peace support operations. Post-conflict situations are complex, and addressing security and insecurity issues is therefore challenging. Evaluations, field reports and research have frequently highlighted challenges related to how assistance is provided in connection with police reform. A common finding in these evaluations is that police reform programmes without local ownership and community involvement and support have little chance of succeeding. Community-oriented policing (COP) has therefore become an important policing philosophy and strategy in this context. This paper addresses issues related to the challenges in implementation of police reform by exploring the perennial question of how police assistance can be better utilised in a sustainable manner in post-conflict contexts. The paper is divided in two sections. In the first, we identify some key challenges facing international police assistance. Here we discuss six main challenges grounded in secondary literature comprising academic research and police mission reports. In the next section using the example of a broadly based police experts network (PEN) established in connection with the EU-funded research project 'Community-Based Policing and Post-Conflict Police Reform', the paper discusses how such a network can play an important role in contributing to policy formation, education and training programme development for use in police reform projects. The creation of the e-handbook and e-learning shows the potential for such a network to work and contribute in a cross-disciplinary manner. Furthermore, we identify four key ways in which this type of network can contribute to improved international police assistance. The work is exploratory and contributes to understanding of the complexities of police assistance in post-conflict contexts.
\end{abstract}

Keywords: Community-oriented police; human security; police experts network; police reform; post-conflict; sustainability

\section{Introduction}

Police reform in post-conflict [1] societies is an increasingly important part of international peace support operations, and bilateral and multilateral international assistance towards police reform in post-conflict societies has a long and extensive history. Since the 1990s, peace operations in Namibia, conducted by the United Nations (UN) such as 
the Department of Peacekeeping Operations (DPKO) [2] and the United Nations Development Programme (UNDP), have been heavily involved in police reform in post-conflict societies [3]. The UN is not alone in this effort; other actors, such as the European Union (EU) through its Common Security and Defence Policy (CSDP) missions, have supported police reform in Afghanistan, Kosovo, Bosnia and Herzegovina, and Somalia. Bilateral donors, non-governmental organisations (NGOs) and diverse regional organisations are also involved in these efforts [4]. However, the UN is by far the largest contributor to peacekeeping operations when it comes to numbers of deployed police officers. According to the Center for International Peace Operations (www.zif-berlin.org) in its Peace Operations map for 2020/2021, in 2020, the UN Department of Peace (DPO) deployed 9,000 police officers to 13 peacekeeping operations, and the UN Department of Political and Peacebuilding Affairs (DPPA) deployed an additional 50 police officers to its 14 political and peacebuilding missions. The African Union (AU) deployed 1,000 police officers to nine different $A U$ peace operations in Africa, and the EU deployed 400 police officers to $14 \mathrm{EU}$ peace operations outside the EU. Among the almost 12,000 police officers annually deployed to a police reform mission, there are obviously vast resources of experiences and knowledge to be utilised for future police reform missions.

Reformed national police institutions that abide by the rule of law have an important role to play in complex and often insecure post-conflict societies. Their impact in terms of maintaining law and order and providing safety and security for communities is an important prerequisite for trust-based police-community relations and is crucial to governments' legitimacy [5]. The development of a professional, accountable, and representative police service that is capable of serving communities in a democratic way is crucial to the overall 'state-building' project [6-8]. Community-oriented policing (COP) has therefore become an important policing strategy in the context of post-conflict police reform. Nevertheless, evaluations, field reports and research have repeatedly pointed to challenges related to how assistance has been provided in connection with police reform and community-based policing in particular [9]. A recurring challenge within international police reform is the inadequacy of local ownership in the reform processes. A number of researchers have highlighted the importance of local ownership in the design, advocacy, and execution of police reform [10-12]. The advantages of involving local stakeholders are manifold; to do so '... enhances legitimacy, broadens the range of potential supporters of a "people-oriented" form of SSR, reduces the likelihood of elite capture, and enhances the possibilities for reconciling local practices and traditions with basic international norms' [13]. Another important challenge in police reform/assistance is involving a diversity of actors, from both the recipient's and donor's sides. This challenge has often led to issues of coordination and coherence, with each actor serving their own interests. A concurring challenge is the deployment of advisors and trainers from various police cultural backgrounds who may not have the necessary qualifications or experience to work in contexts that are unfamiliar to them $[9,14,15]$. The key question that this paper addresses is as follows: How can police assistance be better utilised to facilitate sustainable reform in post-conflict contexts? After a brief chapter describing the methodology used in this paper, we provide an overview of police reform and the rationale for police reform and COP in post-conflict societies. This overview is followed by an examination of the complex challenges related to police assistance in post-conflict contexts and of how current approaches fall short of sustainable police reform. We then move to a discussion of how to address some of these shortcomings through an innovative approach to police assistance, using our experiences from the pilot police experts network (PEN) developed as a part of an H2020 research project on police reform. We conclude with a discussion of how the combined know-how of such a network can be very beneficial to police services that are undergoing transition and to the development and sustainability of policies, training, and education.

\section{Methodology}

This paper is based on both secondary literature and original qualitative data. The first part of the paper (Chapter 4) addresses some key challenges to police reform and assistance and is comprised of academic research, police mission reports, evaluation reports and studies by organisations and media reports. The overlapping nature of the literature facilitates understanding of the complexities of police reform and police assistance in post-conflict contexts.

In this section, we discuss the differing aspects and barriers to achieving a sustainable COP in post-conflict contexts, and in the next part (Chapter 5); we explain why PEN offers a viable solution.

The second part of the paper (Chapter 5 onwards) is devoted to the formation and contribution of PEN throughout the project period. It is based on qualitative data obtained through discussions, interviews and feedback from PEN members over the last five years of the project period. The project's annual meetings, workshops, regional meetings and final disseminations form the bulk of input from the members. In addition, we sent earlier drafts of the paper to all members for their comments and feedback. Communication concerning specific topics was conducted through e-mail correspondence.

The Norwegian Police University College (PHS) conducted the process of recruitment, establishing and coordination of the network. PHS contacted researchers and requested suggestions for potential PEN members to recruit. We also requested international colleagues to activate their personal networks from previous police reform missions to suggest possible PEN members. In other words, the PEN coordinator spread the news that PHS was recruiting police experts to a network. After considerations at PHS, a formal invitation together with information about the project 
and conditions for membership in the network were sent individually to potential PEN members requesting their acceptance. Therefore, all PEN members were volunteers during the five-year project period.

Table 1. PEN membership development in numbers from 2015 until 2020.

\begin{tabular}{lll}
\hline June 2015 & $\mathbf{2 0 1 6 - 2 0 1 7}$ & $\mathbf{2 0 1 7 - 2 0 2 0}$ \\
\hline 15 & 45 & 62 \\
\hline
\end{tabular}

The above table provides an overview of the number of members who became part of PEN from the project's inception in June 2015 until its termination in November 2020. The figures in the table represent police personnel, academics and civil society members recruited to the network. From 2016 until 2020, the membership varied from 45 to 62 persons. The reason for the variation is that some requested to be released from the network while others were released due to their inability to actively contribute in a sustained manner. Recruitment of new members was an ongoing process throughout the project period. Of the 62 individuals who comprised the network, 46 were males while
16 were females coming from 22 different countries. One of the greatest challenges the network faced was recruiting police personnel from Central America due to language barriers since very few can communicate in English and because of the fear of and lack of approval from senior management to become part of a foreign research project.

Table 2 illustrates the number of PEN individuals (police personnel, academics and civil society members) who have post-conflict police reform mission experiences from different organisations.

Out of the total number of 44 police educated PEN members, 36 where working as active police officers during the project period, 8 police educated PEN-members were either retired or had moved on to other professions.

Among the 18 members with academic background, some had a police career prior to their academic career. 21 individuals had experiences as receivers of advices from international advisers, and seven had experiences as receiver and later worked as international advisors.

The rationale behind the establishment of PEN was to establish a forum that could bring together practitioners, academia and civil society in a cooperative collective to better understand the challenges of COP in post-conflict contexts.

Table 2. PEN members with different mission experiences.

\begin{tabular}{lllll}
\hline $\begin{array}{l}\text { United Nations } \\
(\mathrm{UN})\end{array}$ & $\begin{array}{l}\text { European Union } \\
(\mathrm{EU})\end{array}$ & African Union (AU) & OSCE & $\begin{array}{l}\text { Different bi-Iateral } \\
\text { missions }\end{array}$ \\
\hline 20 & 8 & 5 & 7 & $\begin{array}{l}\text { Non-governmental } \\
\text { organisations } \\
\text { missions }\end{array}$ \\
\hline
\end{tabular}

Table 3. PEN members' background.

\begin{tabular}{llllll}
\hline $\begin{array}{l}\text { With police } \\
\text { education }\end{array}$ & $\begin{array}{l}\text { Working as an } \\
\text { active police } \\
\text { officer during } \\
\text { project period }\end{array}$ & $\begin{array}{l}\text { Background } \\
\text { from academia }\end{array}$ & $\begin{array}{l}\text { With experience } \\
\text { from one or } \\
\text { more police } \\
\text { reform missions }\end{array}$ & $\begin{array}{l}\text { With } \\
\text { experiences as } \\
\text { receiver of } \\
\text { police advice } \\
\text { (Host country) }\end{array}$ & $\begin{array}{l}\text { Experiences as } \\
\text { both an advisee } \\
\text { and later as a } \\
\text { police reform } \\
\text { advisor }\end{array}$ \\
\hline 44 & 36 & 18 & 40 & $\begin{array}{l}\text { Background as } \\
\text { instructor at a } \\
\text { police } \\
\text { education } \\
\text { institution }\end{array}$ & $\begin{array}{l}7 \\
8\end{array}$ \\
\hline
\end{tabular}




\section{The Rationale for Post-Conflict Police Reform}

As mentioned above, international assistance that supports security, development, and human rights is a crucial component of post-conflict programmes. Internal security is an important prerequisite for economic, social, and political development and a cornerstone of state-building. As Winkler argued, 'without security there can simply be no sustained development, nor any progress towards democracy, stability and peace' [16]. An equally important pillar of state-building and democracy in any society is a wellfunctioning, trustworthy, and accountable police service that works with other rule-of-law institutions. In the words of $\mathrm{Ca}$ parini and Marenin, 'a democratic police and a democratic society exist in symbiosis. Without a supporting democratic context-a culture of tolerance and trust, a supporting legal framework and a system of functioning criminal justice institutions-democratic police cannot be created' [17].

The police are thus an important part of a system of governance $[18,19]$, and police reform is dependent on broader democratic changes in society. But what do we mean by police reform? According to Eide and Holm, police reform is part of the 'law and order triad comprising police forces serving the public, independent judiciaries, and penal systems' [20]. Numerous police reforms have been implemented throughout Europe and North America as countries moved away from authoritarian states towards more democratic forms of government [17]. While policing in countries that have undergone major reforms may not always be fully 'well-functioning, trustworthy and accountable [21], such countries nevertheless aspire to international standards of policing based on democratic principles.

In post-conflict societies, police reform is particularly challenging and complex. This complexity is apparent immediately following a conflict, when the transition from militaryto civilian-based security is not well understood. In this transition, the role and responsibilities of the police are unclear. The examples of Iraq and Afghanistan highlight this dilemma: on the one hand, the police have to use military skills to deal with and fight armed insurgencies; on the other hand, they have to address internal law and order situations. Many scholars have emphasised the advantages of a clear delineation between these two roles, especially when countries move from conflict to post-conflict situations [5,14]. Pino and Wiatrowski argued that '.. the use of paramilitary police can result in force being used inappropriately and can alienate a population from the police who should seek to serve them' [22]. Other scholars have emphasised the dilemmas that result from having a police 'force' that can deal with armed insurgents, especially after periods of conflict, when the situation is fluid. Such scholars cite Iraq and Afghanistan as examples of countries where armed conflicts and counterinsurgencies are still prevalent and where the boundaries between the military and police are often 'blurred' [23,24]. This dilemma, namely reform aimed at addressing immediate security issues versus long-term capacity building to address human security issues, is at the very heart of police reform in post-conflict societies. According to Bayley, four fundamental criteria must be met if police reform is to be successful in post-conflict societies: police must be accountable to law rather than to government; police must protect human rights, especially those rights that are required for the sort of political activity that is the hallmark of democracy; police must give top operational priority to servicing the needs of individual citizens and private groups; and, finally, police should be transparent in their activities [18]. On the other hand, Manning (2010) points to a clear distinction between the concept of accountability, which is to be encouraged, and that of transparency which, because of the nature of policing and the need for secrecy and discretion, may not be an attribute to recommend to policing organisations [25]. However, these criteria are challenging in post-conflict societies, where police institutions are often viewed with suspicion and mistrust and associated with insecurity, abusive behaviour, and corruption. Thus, relations and trust between the police and the community are typically extremely weak in these contexts. Given that these problems surface in many post-conflict contexts, Bayley [26] raised the question of why there is no shared knowledge on how to tackle them. Instead, the focus has often been on building policing institutions to address 'hard security', such as combating insurgents. Such a preoccupation with combating insurgents often leads to a neglect of human rights and other democratic mechanisms. Unfortunately, there is no evidence that such approaches build trust between police and communities.

In recent years, however, the international policing policy community has shifted its focus towards approaches which seek to work closely with communities to address problems of trust and accountability. One such approach is COP [27]. Over the years, acceptance of this approach has gained ground within the UN and the EU and among different policymakers, police practitioners, educators, and NGO $[17,28]$. Some scholars have argued that-because of its principles of engagement, collaborative approach, responsiveness, problem-solving methods, and accountability-COP is a suitable model for re-establishing the broken links between police and communities [29-31]. Others have been critical of this approach, calling it a Western model for policing strategies and even questioning its impact and effectiveness [32-34]. Still other scholars have pointed to the shortcomings of COP, claiming that it collides with local customs and traditions of conflict resolution and justice mechanisms [35]. The question therefore emerges, how can COP be successful in post-conflict societies? For this to happen, Brogden suggested the following: ...the key requirement must be that the initiative is local in character. It must draw on local experiences and practice in terms of what works. It should only borrow from the West when two conditions are satisfied. Those policing goods must come with an attested success record. Second, they must only be implemented when they are constructed through the benefit of local knowledge and sensitivity to local conditions and legitimation. Public ownership of policing, not state or police 
control is the key to communal policing in many transitional societies [33].

Brodgen argued that if COP is to be successful, those working towards reform must have the competence and capacity to understand complex local contexts and be able to facilitate the development of sustainable relations between the police and communities in ways that build trust and improve human security. This is true for police reforms led nationally in times of relative peace and for police reforms in post-conflict contexts, where the international community often plays a strong advisory role. The concept of sustainability, however, is not well understood, particularly in these difficult contexts. The World Bank report (2016) [36] mentions this crucial point when it highlights the challenges and patience required to reform police and justice systems. The report outlines the importance of support from dedicated senior police officials, the need for patience when changing structures and routines that have long been in place and the need to nurture and follow up on the changes over a period of time. As the report emphasises, 'Change requirements will need to be well understood, well sequenced, and given the time needed to mature. The more encompassing and fundamental the change, the longer it will take to become institutionalized' (p. 8) The next chapter examines the concept of sustainability, specifically in the case of post-conflict police reform when the international community provides police advisory assistance, and explores the challenges faced by international police assistance to COP.

\section{Challenges of Sustainability in International Police Assistance to Community-Oriented Policing}

A recurrent theme in post-conflict police assistance is the perennial challenge of sustainability: How can police assistance be effective after the donors have left the scene? A common complaint running through many case studies on post-conflict reform concerns the lack of sustainability, especially pertaining to local ownership. As a concept, sustainability rose to prominence in the 1980s with the publishing of the World Commission Report on Environment and Development (popularly called the Brundtland Report). The report defines sustainability as follows: 'Sustainable development is development that meets the needs of the present without compromising the ability of future generations to meet their own needs' [37]. Although the term was initially applied to environmental issues, it was later expanded to include social and economic issues [38]. In order to preserve the earth's ecosystem in an equitable manner, it is necessary to create community capacity that fosters effective participation and equitable treatment of all stakeholders while also maintaining an economic system that provides a decent standard of living for this and future generations. As Basiago concluded, "only by "integrating" and "interlinking" economic, social and environmental "sustainability" can negative synergies be arrested, positive synergies fostered, and real development encouraged' [39]. Although the term 'sustainability' continues to be primarily associated with the developmental and environmental sciences, its core content can be usefully applied to human security and police reform. The concept addresses key issues of empowerment, participation, accessibility, and institutional stability-all of which are important components of post-conflict police reform.

In its simplest form, sustainability in the context of police reform assistance 'evaluates the ability of the police service to sustain itself and its capabilities without international donor support and guidance [40]. Building sustainable peace requires an improved police service that has a lasting positive impact on the security and safety of communities by enabling threats, such as everyday crime and terrorism, to be capably and efficiently dealt with after the international actors have left the scene. There is no denying the fact that carrying out police reform/assistance in fragile states is a daunting task, especially given that policecommunity relations tend to be weak when such states have undergone or are undergoing crises. As Narotzky and Besnier stated, 'Crisis refers to structural processes generally understood to be beyond the control of people but simultaneously expressing people's breach of confidence in the elements that provided relative systemic stability and reasonable expectations for the future [41]. Facilitating reforms against the backdrop of such political, financial, social, and logistical challenges requires patience and a continuity of effort. The responsiveness and participation of all local actors is of crucial importance and a critical prerequisite for achieving a long-term effect on police-community relations and building a capable, effective, and trust-based institution. Without local involvement and support from all stakeholders, police reform initiatives will have little chance of succeeding. Likewise, an understanding of local context is central, but not always emphasised in police reform processes. Understanding the specific circumstances of insecurity for different people and how it affects their lives goes a long way in being able to contribute to and protect their well-being. Police reform focusing on COP has the potential to address these areas in ways that conventional police reforms have failed.

\subsection{Challenges: Local Ownership from 'Counterparts' to Communities}

There has been continuous debate, both at the policy level and at the operational level, about what exactly 'local ownership' means for donors and recipients. As Donais summarised, '... local ownership remains a contested concept in both theory and practice' [12]. Participants in the debate tend to position themselves along a minimalist-maximalist axis. For the minimalist, 'locals' are national-level political elites, who are presumed to possess both the capacity to implement reforms (with outside support) and the legitimacy required to ensure broad public support for reforms. The maximalists, in contrast, argue that locals should integrate a wider support base, particularly domestic civil society, as a key set of local owners [12]. Eric Scheye outlined four levels of ownership: national government and elite, local 
government and elite, justice and security service providers, and customers of the goods delivered [42]. Although this outline seems simple and straightforward, this is not in fact the case, as all four levels face their own challenges. As mentioned above, reform is carried out in societies undergoing a transition from crisis to normalcy, and, in many cases, the state may be too weak to respond to immediate security and reconstruction challenges without outside help. In some states, government stakeholders may have their own vested interests in establishing a power base and authority for themselves rather than attending to the needs of the population. According to Donais, 'In many cases, political elites may be neither representative nor enjoy widespread legitimacy, with the resulting gap between government ownership and national ownership producing only a thin veneer of reform that fails to penetrate into society at large, ...in other words, while local political elites may be the most obvious local owners, they can also be the most problematic' [12]. Mani pointed to three types of local spoilers that can disrupt progress towards sustainability: political actors in the form of corrupt ministries; economic actors that wish to protect their activities (e.g., criminal groups); and institutional actors that are afraid of losing their sphere of power, authority, and influence in the new scheme of things (e.g., the military) [43].

Criticism has also been levelled at 'local ownership' from a donor perspective. As Rathmell [44] critically highlighted in the case of Iraq, training courses, plans, concepts, policies, and procedures came from abroad or the International Zone and were translated into Arabic and given to Iraqi counterparts in the false name of local ownership, using phrases such as '...what the Iraqis need is...', 'putting an Iraqi face on ...', and 'obtaining Iraqi buy-in...' [43]. In a similar fashion, with reference to the Kosovo mission, Erik Scheye [42] described how UN officials claimed that they had 'consulted' their Kosovo counterparts on police reform in the country. However, the story from the Kosovan side was that '...the UN consultation process was a polite form of external imposition and therefore they believed that they had little to no ownership of Kosovo's JSSR programme' [42]. Some researchers have pointed to a Western-centric approach to police reform, in which the focus is on Western-style reform and policing models [33]. Bayley argued that international police reform focuses on issues that are beneficial for donor countries rather than recipient countries [6].

A critical question that emerges from the above discussion of police reform is how power and power relations can influence police reform efforts in post-conflict countries[12,32,33,45]. As Divon reminded us, 'power is a constant feature in these relational mechanisms and manifests through the hierarchy presented in the exportation of models moving across through training, "knowledge", "experience" of "best practice" and success stories in the West' [45]. This unevenness of power relations was further addressed by Roderick Evans, who stated that '...more often than not it has been western experience and models inappropriate in developing country conditions that have informed these technical solutions... that are at odds with national and institutional culture. Enormous effort and resources can be wasted in creating institutions, structures and processes that are not "owned" by counterparts, will not work in the local environment, are unaffordable and are therefore not sustainable in the long term'[46]. As previously noted, post-conflict situations are complex and varied and involve a plethora of actors and shifting power relations, as international, national, and local actors and institutions compete to define and describe the realities on the ground. In this process, some institutions and interests become stronger while others become weaker. 'Reforms of policing are about policing but also about power and politics and must be attuned to the political realities on the ground' [47].

\subsection{Challenges: Human Security and Trust}

An additional factor that can affect the sustainability of police reform is the degree of contextual knowledge about the ways in which a broad range of insecurities affect the lives of different people. Moving away from a narrow understanding of security as exclusively state security, the concept of human security considers various forms of interlinked insecurity (e.g., economic, food, health, environmental, personal, community, and political security) [48]. The concept recognises violence and poverty as major threats that are related, although in ways that may not be immediately apparent, and-in its broadest sense-focuses on human vulnerability, encompassing threats of all kinds [49]. Therefore, understanding the contextuality of insecurity is very important, as it allows for understanding how communities are affected by issues of risks, vulnerabilities, and protection and how capabilities and empowerment can serve to secure their lives [50].

A lack of understanding of human security issues that affect the everyday lives of citizens and their local cultural norms, practices, and traditions-whether they are related to personal safety, domestic violence, or threats related to inheritance rights to land-hampers progress towards sustainable police reform. For example, UN Police (UNPOL) officers deployed in Timor-Leste had very limited knowledge about the local history, culture, language, and laws. This lack of knowledge became a problem, especially when officers had to interact with the local population [40]. Having local knowledge gives reformers a firm foothold, enabling them to understand the realities on the ground related to security and insecurity issues, how they affect communities, how to address them, who should address them, and in what ways. As Marenin articulated, local knowledge allows for understanding '...which insecurities bother people the most, which aspects can be addressed most easily, what practices are most feasible, which will have the largest pay-off in the sequencing of reforms, or which leads to a better sequencing of reforms' [10]. However, being culturally sensitive to 'local knowledge' does not mean that one has to turn a blind eye to issues affecting basic human 
rights, such as domestic or gender-based violence or child abuse. Understanding the context of culture and tradition can enable one to develop policies and interventions that can bring about change. In the study of police-community relations, a human security approach provides ample scope for analysing the different actors and institutions that contribute to or threaten the security of citizens. A human security, people-centric approach emphasises that insecurities are not only multiple, but interrelated and therefore cannot be understood in isolation.

The question remains how we can better understand the complexities of sustainability in post-conflict settings and how the complexities can be addressed in a more integrated manner, accounting for the social/political context, the actors involved, and the possibility for local ownership. Marenin neatly summarised these considerations as follows: Strategic lessons on how to approach reforms of policing can be grouped into these categories: understand the nature of policing; appreciate the generality and the specificity of local contexts; develop a strategic approach to the resilience of local histories and conditions; be aware of sequencing dynamics—needs and demands will change as reform becomes institutionalized; focus more on creating and sustaining a process of change and innovation and less on creating organizational structures; think long term as well as short term-international assistance will disappear by the priorities of donor not the needs of recipients; think circular and not linear; and learn from positive as well as negative experiences [10].

The issues of personal security and livelihood security are interconnected, and there is a need to bridge the gap between them in order to understand how local communities tackle their human security needs and how different institutions, such as the police, can contribute. The question of ownership or sustainability goes to the core question, How can trust between citizens and the police be fostered and increased in post-conflict societies, especially where the police may be the cause of insecurity? As previously noted, COP is often considered to be an appropriate model for resolving mistrust between citizens and police through its focus on principles for fostering community engagement, including 'partnership, working together, responsiveness, service, accountability and transparency' [51]. But how are these principles operationalised on the ground? In Kosovo, UNDP carried out a public opinion survey to gather information about how the Kosovo Police Service (KPS) was perceived by citizens, especially in relation to preventing crime and providing security. This survey sought to assess the impact of human rights training that was mentored and monitored by the UN Civilian Police (UN CIVPOL) [3,52]. The survey concluded that 'a majority of Kosovans now perceives the police as a trusted and credible institution' and that the KPS 'must further broaden public trust and engage communities through regular dialogue about steps to jointly improve current levels of safety and security' $[3,53]$.

An international NGO in Sierra Leone similarly conducted a security sector survey in order to assess people's security concerns. The perception survey-conducted in collaboration with various stakeholders, government and security officials, NGOs, and local representatives in several parts of the country-measured the perceived security concerns of people before and after the conflict in 1991-2001. According to the results, the key concerns regarding citizen insecurity included crime (especially violent street crime), drug abuse and smuggling, rape and domestic violence, child trafficking, and youth unemployment. With respect to relations between citizens and the police, the general impression was one of improvement: about $40-50 \%$ of the population in each district had positive relations with the security forces [54]. As one of the key security concerns of the local population was domestic violence and child abuse, family support units (FSU) were established to identify, train, and help police to prosecute offenders [54].

Following the Good Friday Agreement in spring 1997 in Northern Ireland, an independent eight-person commission headed by Sir Christopher Pattern was established to recommend police reforms [55]. The commission itself resembled a miniature PEN consisting of experts from the fields of policing, politics, law and civil management (the report chapter 2.1). The commission conducted meetings with civil groups within Northern Ireland (NI) covering all aspects of the civil society and relevant institutions abroad and conducted 40 public town hall meetings over 10 months all over $\mathrm{NI}$ in addition to a number of other meetings with individuals and interest groups (Report Annex 2-3-4). The so-called Pattern Report, 'A new Beginning: Policing in Northern Ireland' listed 175 recommendations of how to change the militarised $\mathrm{NI}$ police into a community-oriented police service.

The above-mentioned surveys highlight the importance of creating a platform for interaction among all stakeholders concerned with police reform and human security, the ability of local populations to voice their concerns on issues of insecurities, and possible areas of improvement for policecommunity relations. Involving local actors is an important step in terms of learning about and addressing community needs and challenges. As such, a platform can be created for community empowerment and active participation in addressing issues of security/insecurity through finding local solutions.

\subsection{Challenges: Short-term versus Long-term Timelines}

The effects of conflicts can be devastating, and the forms of necessary resolution vary. For example, some postconflict situations call for immediate conventional security assistance for a short period, while other situations involve processes of revival and rebuilding in a long-term timeframe. Even within the same society, some parts of society will experience relative peace, while others will face violent threats in the form of insurgencies, be exposed to armed conflicts, or experience a general lack of law and order. Therefore, post-conflict societies need a police service that can deal with immediate threats of insurgency as well as 
tackling day-to-day law and order issues within and between communities. Despite much progress, international police reform processes have not been able to reconcile these two aspects. Time and again, evaluations reports and research have pointed to challenges in the way in which police reform assistance has been provided, but have not acknowledged the types of assistance and support which are needed for long-term impact $[4,44,56]$.

The paradox in post-conflict contexts is that there is a strong inclination to view police reform primarily as an attempt to respond to immediate security situations that require quick-fix solutions. Long-term, comprehensive strategies for competence and capacity building consequently take a back seat. Rathmell et al. emphasised this trade-off in the case of Iraq, stating that 'The effort to build structures that could serve Iraq well in its transition to democracy was in constant tension with the need to respond to immediate requirements. Inevitably, some of the responses to the immediate security situation, such as a reliance on tribal guards and the creation of a more centralized police command and control structure, were contrary to the coalition's long-term political goals' [23]. In this regard, Bayley critically argued that most international police reform tends to focus on short-term rather than long-term goals, which concern planning, effective resource utilisation, and appropriate implementation $[6,26]$. As Rathmell et al. argued in the case of Iraq, 'The matter of institution building, however, has been largely ignored by observers and policy makers; it is often seen as a long-term issue that is too far removed from immediate security needs' [23]. Bayley and Perito [9] similarly highlighted a number of shortcomings of different missions, especially in Afghanistan and Iraq. Their criticism was directed at conflict management, the lack of proper plans for training the police, a lack of adequate evaluation reports on the impact and result of programmes, and ad hoc decision-making. This criticism was also a common complaint among Norwegian police officers stationed in Afghanistan [57]. A recurring frustration expressed by Afghan police personnel to their Norwegian counterparts was their concern about 'training vs. education'. 'In their opinion training was seen as a short-term measure that addressed immediate tasks at hand, whereas education was seen as a long-term investment in the rebuilding of police institutions' [57].

Caroline Holmqvist posited that good democratic governance is of central importance to reform. According to Holmqvist, two important questions must be addressed: how to engage with the remnants of non-state actors and prevent them from destroying the peacebuilding process and how to help civil society to strengthen the governance of the security sector, both of which are long-term efforts in the reform context $[58,59]$. For Frank Harris, a clear distinction must be drawn between reform that seeks to make a police organisation more effective in terms of general policing objectives (e.g., crime reduction, tackling drug abuse, maintaining public order) and reform that seeks to make a police organisation more democratic. In his opinion, there is 'considerable consensus amongst reformists about what the police "do", but far less agreement about "how" the police should do their work' [60]. However, as Ziegler and Nield [8] noted, the two perspectives on police reform, the short-term and long-term approaches, need not be at loggerheads, because carrying out proper crime control and maintaining public order require a police service that is democratic, respects human rights, and abides by the rule of law.

\subsection{Challenges to Coordination and Collaboration}

Police assistance in post-conflict contexts involves different actors-both national and international-representing different policing cultures and traditions. As a result, there is often a lack of proper coordination and collaboration between organisations, giving rise to significant overlapping, confusion, and incoherence in police assistance. This lack of coherence and coordination on an international stage, where power in reform is held externally, was described by Ashraf in the case of Iraq. He described how 'The Western politically inspired rush to complete the job in Iraq created a doctrinal tension between the active law enforcement approach of the UK military and the community based consensual approach of the UK police, which reflected the fundamental difference in objectives (and therefore approaches) of the two security services' [61]. A similar concern was also voiced by Norwegian police officers serving in Afghanistan, one of whom remarked, 'everyone wants coordination, but no one want to be coordinated'. Germany was originally assigned the role of 'lead nation' in Afghan police reform due to its history of providing support to education, training, and the development of a civilian police force in the 1960s and 1970s [24]. Critics, however, have charged that the coordination on Germany's part was slow, haphazard, and confusing, which resulted in different nations essentially carrying out their own projects without proper collaboration [57]. The result was multilateral organisations, regional organisations, bilateral organisations, International Governmental Organisations (IGOs), NGOs, and other organisations with different agendas and power bases participating actively at different levels and in different parts of the Afghan community.

A further example from Timor-Leste demonstrates a lack of coordination and harmonisation among donor countries. In Timor-Leste, UNPOL was responsible for assisting and training the Timorese police. However, as Bajraktari et al. detailed, 'These trainings were led by UNPOL "project experts." However, without a standardized UNPOL training model, UNPOL officers offer various training models depending on their own national background and police training. This lack of uniformity creates confusion among the PNTL' [40]. A similar complaint was registered in Kosovo, where police training was conducted by instructors from diverse policing cultures, who provided different police training to the local police. In short, there is significant variation 
in how community policing is interpreted by different actors, which can cause confusion and misunderstanding; these challenges can become magnified when refracted through the structure of power-relations between donors and recipients.

\subsection{Challenges: Quantity vs. Quality}

One of the recurring dilemmas facing police reform missions is the dichotomy between quantitative capacity assistance and qualitative reform; reforms are commonly criticised for overemphasising the former at the expense of the latter. In considering the objectives and strategies of various police missions, the importance of quantitative assistance (such as increasing recruitment numbers, the number of people trained, and the quality of the technical assistance provided) is clear. While there is no denying the importance of quantitative assistance, Bayley [26] affirmed that mere technological investment is no guarantee of a responsive and effective police service. In his words, 'although it is easier to increase the technical capacity of police than to change their behaviour, doing so makes little, if any, contribution to democratic policing. It turns out that what is easiest to change-namely technical capacity —is the least important; what is hardest to change - namely, institutional behaviour-is the most important' [26].

Another common argument that arises in post-conflict missions concerns recruitment. How can the 'right' people be recruited in the 'right' numbers, especially in post-conflict societies where the state is weak, and unable to respond to security and reconstruction challenges without external help? This question articulates the need for a focus on 'quality' in reform. Local police may be more concerned with establishing their own power base among local elites than engaging with local communities, vulnerable groups, and minorities and protecting them from violence. Moss pointed to this dilemma in his article about the recruitment of Iraqi police officers after the American invasion, quoting Stephen White-a retired British police officer-who remarked that 'local political leaders appointed police chiefs who in turn hired their friends, relatives and tribesman' [62]. This phenomenon is linked to another recruitment challenge: the difficulty of representation in societies that are ethnically, religiously, tribally, and linguistically diverse. For COP to be effective and successful, the police service must both resemble and represent diverse communities, which can promote legitimacy and build trust, while simultaneously possessing skills in communication and negotiation. In an effort to address this goal, some scholars have also advocated for the use of merit media and affirmative action in police recruitment processes $[40,63]$.

\subsection{Challenges: Lack of Relevant Training}

A key component in police assistance to post-conflict areas is training local police in fighting crime, protecting individuals, and upholding law and order. Yet, according to Bailey and Perito [9], many of these programs fail to properly address the needs of the recipients in their training regimen. 'Too often, reforms are suggested or training offered that reflect what can be given rather than what is needed' [9]. Furthermore, these reforms tend to operate under a 'one-size-fits-all' mindset, neglecting the critical requirement that police assistance be grounded in the local realities of culture, traditions, and history to ensure successful implementation [64-66]. Hansen [67], in his work on the Horn of Africa, proposed a set of assumptions regarding the role of the state in security that are sometimes made regarding police reform towards COP. Many police reform advisors come from 'Western-style' societies where the state is in control of providing justice and security to the population. However, in many post-conflict areas, state-controlled security/justice is not the norm; in communities without central state presence or control, there are other mechanisms for providing security and justice. There may even be different structures in different parts of the same country. Indeed, 'one size will not fit all.' The importance of grounding police reform in the local context is global. In South Asia, for example, Nawab et al. [68] referred to the importance of understanding the legitimacy of local institutions-such as jirga in Khyber Pakhthunkwa, Pakistan-when trying to build trust between communities and the police. Similarly, Nyborg et al. [69] cited the importance of learning how local institutions themselves have reached out to the police to work towards improvements in the community's human security, even prior to the introduction of a formal COP reform process. This awareness of local context is crucial in the development of general curricula for trainers if they are expected to make any long-term impact.

Still, even if trainers are grounded in the local context and equipped with a quality curriculum, Peake and Bailey $[26,70]$ concluded that the knowledge and experience of practitioners is not being properly utilised at home and abroad. According to Bayley, 'the people that do assistance work, both at home and abroad, know a great deal about what works and what does't, but this knowledge is not being captured' [26]. A related challenge is the lack of continuity in training; 'how to retain and pass on institutional memory remains a real issue' [54]. Beyond these questions of 'how' are questions of 'who' should provide training. Many training programmes enlist police officers sent by donor countries who lack adequate competence in the training of local personnel and are unable to deal with local realities $[14,71]$. Furthermore, it is often the case that 'the people recruited to train local police abroad are themselves untrained in curriculum design or pedagogy...'Training and mentoring require special skills and the ability to adapt them to different environments. Successful training abroad begins with better training at home' [9].

Police reform and assistance is positioned in an intricate landscape with significant variation between different contexts. The complex and diverse issues surrounding human security in post-conflict areas require adequate knowledge grounded in local understanding to answer the questions 
of how and by whom these challenges can be addressed. Still, the pursuit of such knowledge creates its own set of considerations, challenges, and questions (including how training should be carried out and by whom) that must be considered to ensure local buy-in and sustainability.

\section{A Police Experts Network for Police Reform Projects}

As previously noted in this article, police reform in a postconflict society is a long-term commitment and task. Given the nearly 12,000 police officers who are at any given time engaged as police peacekeepers/advisers worldwide [72], the risk of losing valuable knowledge and experience due to constant personnel turnover is clear. As the vast majority of these 12,000 officers are on a 12-month maximum deployment from their respective police organisations, there is a high risk of loss of corporate memory. As Bayley (2001) contended, there is a need to share knowledge on how to understand and tackle the lack of trust between police and communities in post-conflict situations. There is also a need to understand local contexts, including historically, to understand how police reform in each case can best be facilitated. One way to contribute to better sharing and use of knowledge on community-based police reform is through a dedicated network of policing experts. Although many policing networks exist internationally (even some with a focus on COP), they tend to be networks comprised exclusively of police. Due to the complexity of community-police relations in these difficult contexts, there is value in expanding such networks to include a broader base of expertise by integrating members of civil society and researchers. In the following sections, we introduce the case of the PEN established under a European Commission-funded research project and share the experiences and lessons learned from this unique group of people. We argue that such a network has great potential to contribute to the quality of police assistance and to a better understanding of how to facilitate bottom-up reform processes in post-conflict contexts.

\subsection{The ICT4COP Police Experts Network}

The idea of establishing a PEN was launched as an integral part of the five-year, EU-Horizon-2020-funded research project 'Community-Based Policing and Post-Conflict Police Reform' (ICT4COP). The focus of the project was to explore the potential of COP to build trust between the police and communities in post-conflict contexts. The aim of establishing a network of police experts in the research project was threefold: to harvest knowledge, experience, and expertise from police practitioners, researchers, and civil society actors with field experience in post-conflict police reform; to engage in knowledge creation between practitioners and researchers on community-based policing practice and experiences in different contexts; and to create a broad knowledge dissemination network. A core consortium partner, the Norwegian Police University College (PHS), coordinated the PEN. As coordinator, the PHS was responsible for identifying and recruiting relevant police experts, including international police advisors, national police experts from the case countries being studied, local and international civilian experts, academics, and members of civil society groups including NGOs.

Membership in the ICT4COP PEN is voluntary and represents an individual commitment, under which members are expected to represent their own knowledge and professionalism, not their institutions [73]. At the same time, members are free and highly encouraged to make use of the knowledge gained through the network in their institutions and professional networks. Network members are recruited based on their experience in international or national police reform and knowledge of community-based policing in postconflict contexts, as well as their unique knowledge of the local context. As an integral part of the ICT4COP research team, the PEN meets together with researchers annually to discuss emerging findings and offer insights and advice on how to understand and contribute to positive change in the policing world; they are also in contact between meetings when needed. While the original PEN was an entity formed to interact with the project researchers for this particular project, the project researchers are also members of the PEN, making the PEN a truly shared forum.

The following sub-sections present the ways in which the PEN operates in order to reach its aims in the project, offering examples from the research process and the lessons learned from this type of collaboration. These examples are followed by a discussion of the benefits that such a network can provide to international efforts towards police reform across the globe.

\subsection{Sharing of PEN Member Knowledge}

The PEN is comprised of about 60 police experts ( $1 / 3$ were female) from 20 countries. Apart from international police experts, the network also includes national police members from Bosnia, Kosovo, Serbia, Pakistan, Afghanistan, Kenya, and South Sudan. The PEN members have prior experience in policing and civil society at the national level, international police advising, and research and training in post-conflict contexts. Two-thirds of ICT4COP PEN members are currently serving or have previously served as police officers. The majority of PEN members have experience as 'police advisors' in different international police reform missions, and many without previous international experiences have experience in being advised by international police experts. Other members have previous experience with working on police reform as civil society actors and academics. The combined knowledge of the PEN members covers multilateral and bilateral police reform missions over the last 20 years and more. All of the major police reform missions since Bosnia in the late 1990s are represented within the PEN: Kosovo, East Timor, South Sudan, DRC (Congo), Colombia, Afghanistan, and Ukraine, among others. Several of the PEN members also have 
experience as police advisors to high-ranked strategic police leaders or political leaders in host countries, Inspectors General, or ministries of interior. Also of great value for the PEN as a group is the individual network that each PEN member possesses, which can be utilised by other individuals. For example, a former advisor to a Minister or an Inspector General will maintain a large network of contacts within that organisation years after her/his end of mission. The project researchers represent an additional 37 members of the PEN, making the total number of members and project researchers approximately 100 individuals. The researchers represent a variety of disciplines, including anthropology, criminology, political science, international relations, development studies, and information and communication technologies, with experience in and beyond the 11 case study countries in the project [74].

The PEN members and project researchers meet at annual project meetings, specific topic workshops, and other meetings throughout the year. In these forums, they exchange knowledge and shared experiences on international police advising, police reform, civil society-police interactions, and police and community awareness and training. At the project kick-off meeting, for example, PEN members presented their experiences in COP through a series of presentations, exemplifying the diversity in both the way in which COP is understood as well as the challenges implementation poses in different contexts. These presentations led to fruitful discussion of the premises and the direction of the research. They also allowed the researchers to learn in which regions the practitioners had experience and their areas of expertise. At annual meetings for the project, PEN members are always invited to give presentations from different police reform projects and share experiences. At the 2016 annual project meeting which took place in Niepolomice, Poland, several PEN members gave presentations of their 'from-the-field' experiences from different police reform processes. There, researchers and police practitioners had a forum for experience and knowledge sharing and discussions on police reform processes in Northern Ireland, East Timor, Kenya, and Ukraine. The discussions at times illustrated how different contexts resulted in different ways to practice COP. Other examples exhibited areas of similar practice. For example, there was a presentation on the case of Northern Ireland, during which a police officer involved in that process shared how the police force in Northern Ireland was reorganised into a civilian police service based on the 175 recommendations from 'The report of the independent commission on policing for Northern Ireland', more commonly known as 'The Pattern Report' [55]. The PEN member explained how the establishment of 'Police Boards' and 'District Policing Partnership Boards' served as a means to re-establish trust between police and the communities and fostered dialogue, accountability, and local ownership. The establishment of local police boards in Northern Ireland was similar to the establishment of 'Local Security Committees' in Kosovo, despite their differing contexts, which led to fruitful discussions on how the groups functioned in each context.

It is also important to share instances of failed efforts in police reforms. In one annual ICT4COP meeting, a PEN member presented his findings and experience related to the first attempt to reform the East Timor police after independence. In his presentation, 'Security sector reconstruction in a post-conflict country: Lessons from Timor-Leste', the member revealed the shortcuts taken by a UN mission to hurriedly establish a new police force by re-installing some 400 former leading officers from the previous Indonesian Police Force (POLRI) after one month of intensive training. The population both before and after independence mistrusted these former POLRI officers and regarded the new police force as suppressors and strangers. In addition, the selection of non-POLRI candidates relied solely on a questionnaire in English developed by Western international advisors, favouring English-speaking candidates over those with knowledge of local dialects and culture. The lack of local involvement in the reform process led to alienation and mistrust in the newly established police communities, and the rebuilding process collapsed in the 2006 riots [75]. The sharing of such experiences helped the members to understand the potential challenges they might face as advisors and provided a forum for discussing how to deal with issues such as historical context and power relations.

In addition to the sharing of experience, PEN members also provide knowledge of political, organisational, and professional aspects of the international and national policing systems. This could include knowledge on the policies central to their work and the methods through which their work is planned and implemented, both internationally and nationally. Finally, the PEN also serves as a 'local information help desk' for the entire ICT4COP research team in the project's case countries. Network members provide valuable pre-fieldwork information about who to contact, who can serve as 'door openers' to individuals in government and police organisations, and which practical arrangements must be made prior to conducting fieldwork. For example, researchers working in East Africa received help from European and African PEN members to identify and contact the proper individuals and institutions, including those in areas where COP concepts are implemented. Members of the PEN have also contributed valuable information on police training and education curricula from project case countries. A PEN member who had worked in police reform missions in Afghanistan, South Sudan, and Ukraine was able to share how the police reform mission in Ukraine adopted training models that were used in Afghanistan and Iraq with very little modifications due to a lack of understanding of local realities. This critical insight shed light on how a 'one-size-fits-all' approach is still a significant challenge in many post-conflict police reform missions. This information was invaluable to the research project, as the policing world tends to be restrictive with the sharing of information. The researchers were also able to obtain documents, such as training manuals and curricula on COP, that are difficult for non-police to access and were offered valuable translation 
assistance for some of these training manuals.

Civil society contributions within the network also form an important knowledge bank. For example, Rozan, an Islamabad-based NGO, works on issues related to gender, violence against women and children, emotional and psychological health, and psychological and reproductive health of adolescents. In the annual meeting held in Oslo 2018, they presented their work in Swat on gender- and sexual based-violence against women. According to their experience, respondents initially did not disclose rape and sexual abuse on their own; it was only mentioned after trust was established between the organisation and respondents. As the topic is attached to a strong social stigma, it would be impossible for an outsider to gain insight and access.

A PEN member from Afghanistan with experiences from Tadbeer, a NGO based in Kabul, provided insight and knowledge around issues concerning human security, insecurity, trust building between police and communities, and developmental issues. Tadbeer had taken initiatives to institutionalise community policing at the ministerial level in Afghanistan. For this purpose, they wrote a communitypolicing consultation meetings manual. Concepts such as communication skills, problem solving, and conflict resolution were highlighted in the manual: terms that were new for both the police and the communities. This manual was ratified by the curriculum Board of Training Command Unit and has become a regular teaching material at the Police Training Command. Similarly, a PEN member from Serbia who works with the Belgrade Centre for Security Policy offered deep insights into human security, insecurity, democratic principles, policing regimes, and human rights in Serbia and the Balkans.

Local and individual experiences reveal the intricate nature of the challenges and dilemmas faced by the people who live in post-conflict societies. Participatory, dialogic process are crucial in understanding and identifying the constraints and challenges faced by communities at the local level and implementing a human security approach at the local level. Integrating civil society groups and other society representatives within the ICT4COP PEN is crucial, as they have local knowledge about people's concerns and insecurities and act as a bridge to bring about successful community policing initiatives.

The diversity of experience among practitioners, researchers, and civil society in the PEN allows for analyses that are significantly different from those that would result if the police or researchers worked in isolation. This collaboration has contributed to an in-depth understanding of how COP can contribute to human security in very different contexts. A new appreciation of the value of combining in-depth knowledge of policing experience, academic reflection, and practical work was developed, and trust was built in the PEN such that even the most difficult issues could be discussed in a constructive manner. Without such knowledge, it would be difficult to address issues of insecurity and security on the ground, including deciding who should address the issues and in which ways.

\subsection{Facilitating Knowledge Creation between Practitioners} and Researchers

A second area in which the ICT4COP PEN has made a unique contribution is in its facilitation of knowledge creation between practitioners and researchers, which goes beyond merely sharing experiences. New knowledge is created through discussion at meetings and workshops but also through the joint development of resources for policymakers, international police advisors, national police, and civil society to use in training, education and implementation of COP in police reform processes.

Examples of such joint knowledge creation in the project (available for open access at www.communitypolicing.eu) are development of the e-learning course 'CommunityOriented Policing for International Police Advisors' and the e-handbook. To develop the curriculum for the course, PEN engaged its members in a series of meetings and workshops. The topic was first discussed at a project annual meeting where police, civil society members and researchers worked in groups to discuss an initial outline of what such a course might include. This initial discussion was followed by a series of workshops over the period from 2018 until 2019 [76] in which existing and newly recruited police experts provided input concerning the course content. The topic was subsequently discussed in detail in further meetings with researchers, who were then able to relate the emerging ideas to research results from several regions and offer insights into how context could be incorporated. During this process, practitioners and researchers in cooperation developed content and scripts and provided valuable comments on and inputs to the final pilot of the course before its release in November 2020. The target group for the course is international police advisors involved with SSR processes. However, the programme is designed in such way that it is relevant to and of value for civilian advisors, NGOs, host country individuals and organisations involved in SSR processes on a national, regional or local level.

The programme consists of four multiple modules:

- Module 0: Introduction to Community-Oriented Policing (What is COP?).

- Module 1: Preparing for Community-Oriented Policing (Before advisors depart).

- Module 2: Co-Creating Community-Oriented Policing (Engaging with local police and community)

- Module 3: Institutionalising Community-Oriented Policing (Creating sustainability)

The e-learning programme represents a co-creation of knowledge by practitioners, researchers, and civil society members to help international police advisors and others involved with post-conflict police reform facilitate and sustain local COP initiatives in an integrated manner. Such an approach increases awareness and knowledge by police entering advisory positions of the value, strengths and challenges of COP. As evidenced by the UN's curriculum development workshop in June 2019 (Strategic Guidance 
Framework presentation later this chapter), the demand for a common curriculum on COP is increasing. Through the development of these products, the ICT4COP project has responded to the need for training and education tools that reflect a broad approach to COP. Such an approach goes beyond an understanding of policing alone to understanding how policing is an integrated part of society and a reflection of historical, political, and cultural contexts.

Another source of joint knowledge creation is the e-Handbook for Community-Oriented Policing. This ehandbook is an interdisciplinary qualitative field-based study combining practical experience from our post-conflict case countries, which can stimulate critical reflection and debate about potential opportunities, risks and dilemmas of police assistance and COP approaches and practices. The handbook covers a wide range of topics associated with the complexities of police reform-assistance and implementation of COP. The content development of the handbook was done through interactions where police, researchers and civil society members discussed and contributed valuable inputs on relevant aspects of international police assistance. By combining texts and digital storytelling, the e-handbook provides examples of promising practices and in some cases, concrete recommendations.

The digital stories developed during the project period are also a unique and creative way of communicating individual PEN members' field experiences that can be used for educational and training purposes in understanding the complexities of and imparting knowledge about international police assistance. The process of developing curricula for international police advisors also addresses the desire for resources relevant for a broad international audience, but sensitive to local contexts and bottom-up approaches (a dilemma mentioned in Chapter 3 on the dangers of a 'one-size-fits-all' approach). This is not an easy balance to achieve. For example, through the 'Strategic Guidance Framework' (SGF) program [77], the UN has for years attempted to establish one common curriculum and one lesson plan for the training of international police advisors. In mid-2019, the UN Integrated Training Service established their own PEN of police officers with police reform mission experience, tasked to develop curricula and lesson plans for the 14 days long UN Police Officers Course (UNPOC) where Community oriented Policing is one among other subjects. The aim was to create one global common curriculum for the pre-deployment training of police officers assigned to UN police missions. All 193 UN member countries were invited to nominate individuals, and in June 2019 more than 70 serving police officers met in Brindisi, Italy for a kick-off workshop.

The participants were divided into different curricula development groups, each tasked to create training materials for specific topics. The group tasked with curriculum development for COP was comprised of seven police officers from Europe, Asia, Africa, South America, and Oceania. The idea behind this approach was to harvest experience from different missions and to secure inputs from different geographical and cultural corners of the world, eventually creating a UN curriculum that is neither specifically male nor female, and not particularly Western, African, or Asian. This process is an example of how other organisations can establish a PEN-like network to build on rich individual experiences. One difference between this process and that followed in the ICT4COP PEN is that the ICT4COP PEN also includes civil society actors and academics, which contributes to a much richer discussion of context and how it might be incorporated in training. The ICT4COP project call document specifically point out the establishment of...

"A project-based Police Experts Network coordinated by a core consortium partner, the Norwegian Police University College (PHS), which mobilizes a range of police experts and professionals further linked to key European/international institutions, and police missions which can directly integrate and apply research findings in training/education programs" [78].

Given the complexities of police reform and assistance, several researchers have expressed their desire for a more 'broad-based' group of experts who can assist in a knowledgeable way. The group should not only include police experts, but also social scientists, historians, local cultural experts, and local community leaders, who can draw on each other's insights, knowledge, and experience and contribute in a meaningful way $[3,26,64]$.

\subsubsection{Police expert networks as knowledge regimes}

As we have seen above, there are a number of key actors and institutions involved in police reform and assistance. These actors and institutions are repositories of different knowledge and perspectives. Such knowledge heterogeneity represents a diversity of actors who understand and respond in different ways. There is a rich body of literature that critically examines the various aspects of knowledge regimes, which define, produce, and operationalise knowledge [79]. In this paper, our intention is not to engage in a critical debate on the different dynamics surrounding the legitimacy and power of knowledge regimes, but to use the concept to think about the strength of the different actors and institutions involved with PENs. For this purpose Birgit Urstad's [80] seminal paper, 'Keeping a Diverse WorkForce,' opens up avenues for exploring the advantages of achieving diversity within organisations and institutions through the lens of knowledge regimes. Urstad was inspired by the work of Mary Follett [81], who examined how institutions and organisations can benefit from the strength and nuances of diversity and thereby utilise the full potential of different knowledge arenas in a co-creative and innovative manner. In her paper, Urstad advanced the benefits of a diverse workforce in organisations and explored how actors possessing different competencies can contribute in a creative and meaningful way.

...different expertise voices and creativity of a range of people belonging to various knowledge regimes; offer solutions, innovations, and the ability to reach out to various 
stakeholders and client groups, and thereby the company's ability to create added value improve to a great extent when diversity is actually activated and made relevant [80].

Both Follett and Urstad argued for the merits of having various knowledge regimes that can co-create and contribute in innovative ways to solving institutional and organisational challenges. Following this perspective, we argue that PENs fit into the mould of knowledge regimes. The concept of knowledge regimes concerns how different actors, organisations, and institutions with specific knowledge, understandings, applications, and communication are guided by their own legitimacy, validity, and power.

However, as mentioned earlier, some of the challenges police reform missions face are asymmetrical power relations between donor and recipient, a lack of proper coordination and collaboration among the different actors involved in missions, a lack of proper understanding of local institutions; and challenges related to coherence and continuity. As Eriksen and Schober noted, 'actors and stakeholders not only respond in different ways, but frequently understand the situation in which they find themselves differently as well' [82]. Police expert networks, with their interdisciplinary knowledge composition and collaboration across different disciplines and borders, offer a unique way of addressing and mitigating the above-mentioned challenges in a collaborative manner.

\subsection{Police Experts Network as a Dissemination Network}

One of the key aspects of the ICT4COP PEN is the communication activities undertaken during the project period. These communication activities were carried out locally in the different case countries with the stakeholders, project annual meetings and through the database were PEN members shared their information. As part of the project's overall findings, four regional dissemination workshops were planned where all stakeholders could meet and discuss the findings, results, and exploitation plans. However, only two regional dissemination seminars and workshops were ultimately held [83].

\subsubsection{Dissemination in meetings and networks}

The members of the ICT4COP PEN are from many different institutions worldwide and can share their experiences within their own institutions and other professional networks. The names, educational and organisational background, mission experiences, and work related-background information of all PEN members are generally available for PEN members and ICT4COP researchers through a common SharePoint site. This is personal information each PEN member has agreed to share internally among PEN members and researchers from the ICT4COP project. Members have additional access to other networks, such as the UN Training Unit, Organisation for Security and Cooperation in Europe (OSCE), African Union, and other regional and national networks.
In addition to meetings, a digital platform was developed for PEN members. The idea was to create a forum for communication and knowledge storage in order to enable PEN members and ICT4COP researchers to communicate and share information. The platform in its original form was not very successful, as neither PEN members nor researchers used it actively.

Learning from this experience, the project has created an online knowledge platform called Knowledge-Based System (KBS) where one can easily access project findings, publications, case studies, the e-handbook, e-learning, tech pilots (i.e., information and communication technology projects) and recommendations to policy makers, government officials, police institutions, civil society and researchers. The aim of creating such a knowledge portal is to share research results, outcomes, findings and lessons learned in a way that is easily available to anyone involved in the field of COP or international police assistance in post-conflict contexts. This portal is managed and operated by the University of Oslo. As with any digital platform, resources are needed to maintain and update content, which motivates members to log in and be active.

In 2016, the Norwegian Ministry of Defence initiated a project to create a handbook for military staff for preventing crises-related sexual violence (CRSV), and in late 2017 the PHS was invited to co-edit a chapter of the handbook for civilian police in peace operation missions. In order to assist the Ministry of Defence, selected members of the ICT4COP PEN network were recruited to assist with this CRSV handbook chapter. Over the course of only a few weeks, the editorial handbook committee was provided with inputs based on field experiences from former police advisors from Europe, America, and Africa, representing field mission experiences from Kosovo, Afghanistan, South Sudan, and Haiti, among others. The insights were collected and delivered to the handbook editorial committee at no cost, which demonstrates the advantage of a PEN network as a low-cost way to gather and impart experience and knowledge.

In Pakistan, the PEN members from police, civil society organizations, and academia have had regular meetings (nationally) to discuss COP, share their needs and interests, and provide data and insights. This interaction has built trust between the members in a political environment characterised by limited trust between the government and civil society organizations. The PEN members are working together to operationalise the results of the research in their own work and broader networks.

\subsubsection{Dissemination in regional conferences, seminars and workshops [84]}

The aim of the final dissemination strategy was to share the research results with all the stakeholders involved with COP. The aim was to help stakeholders identify challenges and possibilities in the implementation of COP. PEN members' role in these dissemination activities has been very crucial 
in creating awareness and influencing those involved in decision making to see the benefits of COP.

Conference on community-oriented policing and postconflict police reform in Southeast Europe (the Balkans)

The regional dissemination seminar for the Southeast Europe region (Bosnia and Herzegovina, Kosovo and Serbia) was held in February 2020. Due to the tension between Kosovo and Serbia, the three-day seminar was located in Budva, Montenegro as a kind of neutral ground. JagielIonian University and Bochum University cooperated to host the two-day conference with participants representing ICT4COP researchers, academia (from the Balkans), local civil groups (youth, gender and community network groups, etc.), police representation from Montenegro and 10 PEN members. The head of the Montenegro police attended the opening sessions and was interviewed on national TV from the conference, broadcasting the main messages from the seminar nationwide in Montenegro.

Both universities later highlighted the value of PEN members as points of contact and sources of information before field visits and follow-up meetings with local police authorities and educational institutions. In one of the sessions, a PEN representative presented the final e-learning course created by the PHS. The session emphasised the advantages of having a broad group of people advising and assisting during the making of the e-learning course, which added great value to the end result of the programme.

The second day of the conference focused on institutionalisation of community policing. Here, assessing attitudes towards police and gender-related aspects of local security were discussed. PEN members, both male and female, with experience with Kosovo police, $\mathrm{BiH}$ police and international organisations (UN and OSCE) contributed with their field experiences. Female police officers from different entities in Bosnia shared their on-the-ground experiences during the 'Gender-related aspects of local security' session, which was further addressed in a Q\&A session.

On the third and final seminar day, the focus was on youth-related aspects of local security. The session addressed challenges youth face in these countries, including unemployment, corruption and lack of trust in the police. An important topic that was eagerly discussed was the effectiveness of school visits by the police in strengthening youth-police relationships. The discussion focused on how police follow up on or measure the effects of their visits and efforts with youth. Members of PEN as well as other local police officers and civilian gender and youth activists from the Balkans all expressed their perspectives on and experiences with security in a frank and respectful way. Many participants mentioned as a valuable result of the workshop the way in which discussions were conducted with open and honest arguments from all participants during the evaluation sessions. Participants moved beyond polite political statements and discussed real problems affecting ordinary people's everyday lives and security.
International conference on community-oriented policing and post-conflict police reform in Pakistan [84]

The South Asian regional final dissemination activities were comprised of a one-day conference and a one-day workshop, both held in Islamabad in March 2020. The two-day event provided an opportunity for police organisations and officers, academics, politicians, policymakers, the international community, civil society institutions, the media, technology providers and others to share research, experience and advice concerning efforts to introduce ICT and COP approaches into police reform.

At the conference, information was shared through both presentations and panel discussions with brief Q\&A sessions with the audience. In this way, participation included both presenters and attendees, which provided additional perspectives and questions regarding the concept and implementation of COP.

In his keynote speech, a top police leader outlined the historical roots and role of COP in Pakistan. He was critical towards the current police culture's attitude towards corruption, brutality and lack of accountability and emphasised the need for increased police accountability and police working closely with communities. He also reiterated that COP should be a comprehensive statutory obligation. Another senior police officer spoke of the importance of the environment outside the police that affects their behaviour that is a product of home, society, peers and profession. Changing culture requires change in all of these areas.

A civil society representative outlined the importance of their role in supporting COP efforts related to gender issues in Pakistan. This person described the challenges and violation of personal rights that women face regularly and called for increased provision of psychological, legal and police assistance to women. She also mentioned the attitudinal change model developed to train instructors and police personnel on GBV, stress management and communication skills.

A representative from Rozan (NGO) working with (Gender Based Violence) GBV issues discussed the importance of training processes and the incorporation of ICT into police efforts. His vision of future preventive work and collaboration was summarised with four l's: indigenising structures and initiators, including non-represented groups and innovation.

A media representative mentioned the lack of media coverage of police reform due to its focus on ratings for content generation and the tendency to cover events in a reactive manner rather than a proactive one. She noted that rather than 'bashing the police'; the media should act as a bridge between the state and citizenry to keep track of complaints. For example, the representative mentioned the potential for ICT to play an important role, particularly for social media to bridge the gap between police and citizens.

The workshop focused on sharing experiences and discussing results with various police leaders of COP initiatives. Some officers recounted their experiences with COP initiatives. For example, one officer mentioned the initiative 
of familiarising communities with the police outside of the context of crime by hosting events in the police station to cultivate goodwill. He also mentioned the need for psychological counselling to be available to police. Another officer voiced his frustrations with the lack of proper payment of salaries and the need for increasing salaries as means to fight corruption.

A social media and youth expert spoke about the importance of bridging the gap between police and youth by focusing on social media. He spoke about the importance of police actively using social media to build trust among the young segment of the population. Pakistan's population is comprised of $67 \%$ of youth; therefore, it is important that police understand the role and impact of social media in relation to youth actions and perceptions.

A PEN member led a Q\&A session on the different aspects of international police advising local counterparts on COP. The member spoke of the strength and challenges on the subject of international police advising. In one of the Q\&A encounters, the local police spoke on a topic using very gender-specific terms and exclusionary language. This encounter excluded many of the female police officers present at the workshop. The PEN member [85] suggested that the local police to find more gender-neutral terms to address the topic. The local police asked if the PEN member could make suggestions, which the member refused to do, saying that this should come locally from the group present and especially from the female police officers. The group made some very good suggestions, and the result was that the women police officers freely participated in the session, providing much input on the topic. This encounter showed the importance of encouraging local police women and men to find their own solutions that can go a long way to help build confidence and create sustainable solutions. Both the conference and the workshop are examples of how the PEN network, particularly those members in Pakistan, were able to facilitate high-level and participatory discussions with police, civil society, politicians and the media on how COP could be relevant in their local context of police reform.

\section{Scientific conference on 'Transforming the police: to-} wards accountability and trust'

An online two-day scientific conference organised by Jagiellonian University in November 2020 focused on police accountability.

More than 70 individuals worldwide attended the conference, including researchers from ICT4COP; academics from Poland and the Balkans; police from Poland, the rest of Europe, Asia and Africa; civil society groups from Poland and PEN members. Research findings from Bosnia and Herzegovina, Kosovo, Serbia and Poland on police accountability with sessions on war crimes, police in Bosnia and Herzegovina and police subcultures were presented during this conference.

The final session was a two-hour panel debate where five PEN members each gave a 15-minute presentation on different aspects of police accountability and trust, followed by a $Q \& A$ session moderated by PEN. The main takeaways from this session were the importance of understanding local context when it comes to police development and how to increase police accountability and trust. The importance of how PEN members with field experiences can assist in painting a more complete picture of how to develop local police accountability and trust in cooperation with local police, academia and local communities was highlighted by examples from lack of police accountability and trust in a Kenyan slum. A PEN member presented examples of how the best international intentions of recruiting female police officers to Afghan National Police could result into a de facto recruitment to sexual abuse and harassment due to the lack of understanding of local culture and context by the international donors with good intentions. Another PEN member presented a UK programme on how to recruit volunteers to assist police in solving long-term security issues. A PEN member from the EU-police mission to Ukraine presented a programme for Ukraine police officers on building police-community trust through a domestic violence prevention training. Finally, the presentation of a research project from Norway dwelt on aspects of trust between minority youth and police.

In the following debate and $Q \& A$ session moderated by a PEN member, the importance of dissemination of real experiences from the field was repeatedly mentioned in terms of learning from both best practices and previous mistakes to avoid repetitions. All participants acknowledged the importance of having PEN members who can share their experiences and knowledge from practical work in the field, complementing academia and research on how to increase police accountability and trust.

\section{Webinar on community police in Central America [86]}

A one-day webinar was organised and administered by the Communications and Public Relations office of the Universidad del Valle de Guatemala. The participants included members of police forces and security institutions of the Latin American region who were consulted during the research process, academics who are working on COP and police reform in Central America and experts, advisors and practitioners from international development agencies. The general theme of the webinar was the presentation of results from the three research activities ICT4COP conducted in Central America in Guatemala, El Salvador and Nicaragua. The main topics covered were police reform, democratisation processes, remilitarisation, authoritarianism, ethnic diversity and feminist approaches to security.

The second part of the webinar was a panel discussion among experts based in Santiago, Miami and San Salvador. The topic of discussion was the successes and shortcomings of COP strategies as part of wider police reforms in the context of the high violence and weak institutions in the region. The general concern among the panellists was the increasing authoritarianism in the region's politics and its expression of support of remilitarising policing strategies. 


\subsubsection{Impact of dissemination activities}

The impact of these dissemination activities has given stakeholders impetus to demonstrate interest in and raise awareness of different challenges and possibilities in COP and police assistance. First, the project has managed to establish cross-disciplinary networks in all case countries. By bringing together project researchers, local civilian societies, local police authorities, PEN members and local academia, these disseminations have paved the way for collaboration among local partners involved in strengthening COP activities. Second, the sessions have highlighted some commonalities across cases. This has enabled practitioners, civil society and researchers to exchange knowledge, practices and challenges among case countries. Third, by having representatives from the government and policymakers participate in these sessions, the network has been able to create channels to access and influence ministerial systems to see the advantages of community policing initiatives.

\section{Benefits and Solutions from a Police Experts Network}

Our experience has demonstrated that a PEN along the lines of that in our research project can address a number of the challenges faced by international police officers advising on police reform which we identified at the beginning of this paper.

\subsection{Better Understanding of Human Security at the Local Level}

The crux of the argument that we have been developing in the previous chapters is that carrying out police reform in post-conflict contexts is complex and challenging. Therefore, integrated knowledge and best practices are crucial for understanding the complex issues surrounding human security, police reform, and development at the local level. The community of women, men, and children at the local level who face security challenges are best positioned to understand and voice their concerns. Thus, access to local knowledge facilitates decision-making and empowers communities to take an active role in finding appropriate solutions to their challenges. Understanding the complexities of human security issues and identifying relevant actors and institutions at the local level can provide a solid platform for COP to be successful. It is in this context that we see the strength of PENs. As previously noted, through such networks, international police advisors with extensive experience in various post-conflict contexts team up with national police advisors who have deep knowledge about local conditions and challenges and are in a position to address local human security issues in an integrated manner. In addition, such networks also include civil society (local and international NGOs involved in ongoing projects where police are partners) and international and local researchers who have requisite knowledge and expertise from their re- spective case countries. Indeed, Bayley argued that 'police reform cannot be left to police experts, but must involve area specialists, social scientists, and historians' [26].

Working in this manner, a PEN can draw upon diverse expertise and approach the field as a holistic endeavour. To do so, it is crucial that the actors involved in reform and assistance processes represent the key institutions addressing human security and development.

\subsection{Co-sharing of Knowledge and Experience for Better Local Ownership}

As presented in Chapter 1, a significant challenge in police reform is the dilemma of coordination and collaboration. As we observed, donor countries assisting under multilateral organisations often work at cross-purposes without proper harmonisation, which in turn affects local ownership. Examples of reform missions in Kosovo, Afghanistan, Iraq, and Timor-Leste demonstrate how contributing nations essentially carry out their own projects without proper collaboration. For recipient countries, the result is confusion, as there is overlap between programmes and assistance from the international community. In addition, unequal power relations between donor and recipient countries influence most police reform efforts. A further significant impediment is the perennial challenge of local ownership. When donor-driven agendas prioritise short-term, easily quantifiable solutions instead of long-term processes based on local needs, longlasting sustainable solutions are difficult to achieve. As previously argued in this paper, there is a gap in information and knowledge flow from the local level to the national level and between various institutions in post-conflict contexts. A key challenge is how to facilitate a better flow of knowledge from the bottom-up, especially when most communication is top-down. One ICT4COP PEN member mentioned the importance of understanding and working at the local level:

In relatively recent post-conflict contexts, particularly where conflict may be continuing, I propose there is compelling requirement for Police to develop their own legitimacy that is separate from the politics and corrupt interests of the state. This is critical for the police to be effective in its responsibility to protect the public but may be alien concept to the police and present significant risk to individual officers who may find themselves reassigned, unemployed or worse. Experienced PEN members and their personal contacts in these contexts will have an understanding of these dynamics and may be able to suggest ways to support the police as an organisation and its officers in working towards political independence and to distance itself from corruption in order to strengthen its legitimacy and become more effective [87].

The experiences that we have gained through our project period, during which PEN members worked in close cooperation, reveals the significant potential of a model which links key actors involved in security and development. Our annual meetings and dissemination seminars created spaces where PEN members could identify, address, and debate security 
and development issues on equal footing. The participatory and dialogic nature of these sessions gave ample scope for connecting security and livelihood concerns and finding appropriate solutions and strategies to address them. Working in this manner provides an effective base for securing sustainability and local ownership. For example, gender studies have provided valuable insights into how co-creative forums contribute to knowledge and innovation and help in improving societal and scientific relevance, thereby increasing impact and legitimacy in the field [88].

\subsection{Continuity and Coherence in Development and Training}

Bailey and Perito [9] argued that one of the major drawbacks in many police missions is the predominant focus on training a large number of police personnel without properly addressing the needs of the recipients. 'Too often, reforms are suggested or training offered that reflects what can be given rather than what is needed [9]. Donor countries come with their own understanding of police traditions, education, and training, thereby creating confusion, frustration, and disorientation in recipient countries. As affirmed several times in this paper, lack of coordination is a serious challenge in police reform missions. Moreover, human security issues in post-conflict situations cannot be solely addressed through the security lens, but must also integrate other actors. This is where we see the strength of PENs. For example, ICT4COP PEN members have provided valuable contributions on police training, education, and curricula from project case countries. Examples are COP trainings in Kosovo, Bosnia and Herzegovina, and Afghanistan. This information has been invaluable to researchers, as the policing world tends to be restrictive with the sharing of such information. Another example of partners working jointly is the development of an e-Handbook on COP. Work on the e-Handbook is the combined effort of PEN members who have the opportunity to discuss, criticise, and contribute content in the handbook. In addition, members also have the opportunity to delve into the complexities and challenges of COP in post-conflict contexts. Co-creative processes such as this are not easy, as there will always be disagreements on certain issues and perspectives. Nonetheless, there is a willingness to listen and discuss different perspectives within the group. Such meeting spaces provide the necessary impetus for bringing together the different actors involved in assistance and reform processes. It is in these sessions that the participants in the network can connect the various aspects of human security and development issues in a coordinated manner and discuss the implications in terms of how issues can be addressed and by whom.

Police officers deployed to different international police operations represent an expansive and valuable source of memory that needs to be tapped by policymakers and development actors. However, to date, this knowledge is not being utilised to its full potential. This point was raised by Osland, and Caparini in their policy brief: 'In order to con- tinue to provide relevant, targeted and efficient contributions to international peace and security, Norway should set up a knowledge management mechanism which gathers, systematizes and analyses experiences and lessons identified by police officers who have served in, or provided training towards, peace operations, stabilization missions and other assistance missions' [89]. In our view, a PEN can help in fostering and strengthening continuity and coherence and in preventing the loss of knowledge.

\subsection{Quality of Input}

The complex issues surrounding security and insecurity in post-conflict contexts require adequate knowledge to support human security at the local level. Such knowledge is critical in understanding issues pertaining to human security and how and by whom these issues should be addressed. As noted in the above discussion, local knowledge is of utmost importance. Equally important is the sharing of this knowledge. Previous research has affirmed that there is a lack of knowledge sharing and relevant feedback mechanisms in police reform efforts. For example, the e-Learning programme developed by the ICT4COP PEN is an important platform for knowledge sharing among participants and key institutions involved with Security Sector Reform (SSR). The development of the e-Learning programme is an excellent example of how the PEN both contributed to and shared knowledge. Other arenas of mutual knowledge sharing have been the annual meetings, locally organised workshops, seminars, and regional meetings. Through involving the group as whole, the network is in a unique position to influence the way COP is understood and practiced by those contributing to policy, training, and education in key European and international institutions/organisations/missions. The ICT4COP PEN members work in and have access to other networks, such as the UN, EU, OSCE, and DPKO. As such, the PEN does not replace or compete with, but rather connects with these institutions in a constructive and meaningful way. One PEN member deftly articulated this dynamic:

Much of the evidence you present for the Police Experts Network supports my case for greater recognition and wider use of previously deployed officers and systems to create and access organisational memory. I don't see this in competition or conflict with the multinational PEN, in fact I believe the two systems co-existing and cooperating will deliver added value [87].

Members of PENs can foster the development of longterm institutional cooperation between social research institutions and police training institutions in Europe and in post-conflict case countries.

\subsection{Challenges to the ICT4COP PEN}

The above discussion has identified some key advantages of a PEN which links security and development in an integrated manner. Aside from these advantages, we would 
also like to acknowledge the constraints and challenges of such a network.

Firstly, the volunteer nature of the ICT4COP PEN provides some unique advantages, as it creates an environment that is not beholden to any specific organisation; however, it can be difficult to maintain member interest and involvement, particularly after the conclusion of the research project if there is no coordinating body to ensure and sustain continuing commitment over time. Secondly, a key component of the ICT4COP research project has been the various arenas for dissemination, including annual conferences, regional workshops, seminars, and e-Learning projects. The challenge arises of how to carry out dissemination once the project period ends. Who will carry forward the experiences of the PEN (and how) to relevant institutions and future projects involved with police reform and assistance?.

Thirdly, as we have observed, ICT4COP PEN members have solid expertise and a rich background from different organisations and countries. As a result, the network has a unique pportunity to contribute, share, and exchange knowledge and experience across organisations and national borders. One of the criticisms of police assistance has been the difficulty of passing on knowledge. Albrect and Jackson contended that a serious challenge in police assistance and training is the aspect of continuity: 'how to retain and pass on institutional memory remains a real issue' [54]. This challenge is very applicable to PENs. Therefore, the need to have a coordinating body is of utmost importance to utilise the integrated competence in a meaningful way.

Fourthly, the creation of the e-Learning module was an important contribution in knowledge dissemination. The learning module represents the combined insights of practitioners, civil society, and academia from actual post-conflict contexts, making it a solid platform for knowledge dissemination. However, things change and evolve; some knowledge and information will become obsolete and new information will become more relevant. Therefore, for the e-Learning module to remain relevant, it requires revision and updates at certain periods. This has been possible during the project period. The question remains how to carry out the update process after the project period is over.

Lastly, as with all time-bound projects, the creation of opportunities for collaboration is dependent on funding. Finding the right mixture of expertise, contributing in an integrated manner with both planning and making the right decisions and to be able to communicate with the concerned parties is dependent on adequate funding. As PENs are voluntary networks, it is difficult to ensure continuing commitment over time. Creating funding mechanisms is therefore vital for the survival of such groups.

\section{Conclusions and Recommendations}

Police reform and assistance is carried out in a very intricate landscape. As conflicts and their effects are not only disastrous, but also varied, post-conflict contexts differ from place to place. The complex issues surrounding security and insecurity in post-conflict contexts require adequate knowledge to support human security at the local level. Such knowledge is critical to understanding issues pertaining to human security and identifying how, who, and in what ways these issues should be addressed. Research and different mission evaluation reports have demonstrated serious shortcomings in the provision of police reform/assistance in post-conflict contexts. An important cornerstone in police reform is a reformed national police institution that is equipped to deal with crime and other threats, to create an awareness of safety and security, and to have a positive impact in communities. However, as we discussed in Chapter 1 of this paper, situations in post-conflict contexts are often fluid and fragile, and police institutions may be weak and lack trust in communities. Research and prior experience have revealed how reform efforts often lack mechanisms for interacting with communities, learning more about their particular security needs, and finding ways to work together and address them. The best way of achieving these goals in diverse and volatile post-conflict environments occurs not only at the policy level, but also at the local level together with those whose lives are actually at stake. Without community involvement and support, police reform efforts have little chance to be successful. In order to achieve success, police must have the capability of building trust-based relations and networks with a diversity of societal groups.

Community-oriented policing is an important policing approach that provides a platform for building and restoring police-community relations. Its strength lies in collaborating with the community, creating accountability, and finding appropriate community-based solutions to local issues. A critical perspective that we raised in the article is the importance of grounding reform and assistance on local ownership. International police assistance is dominated by a top-down approach. External assistance and programmes are imposed on local actors without properly understanding local challenges, dilemmas, needs, and solutions. This approach can undermine local ownership of reform and assistance, leading communities to view such efforts as externally imposed programmes. As Scheye explained, 'In a very fundamental way, therefore, both security sector reform and the broader debate over ownership revolve around the question of how international norms can be reconciled with local realities in ways that actually enhance the day-to-day security of those living within the reforming state' [90].

This paper argues that PENs are unique knowledge networks that can address these challenges in an integrated manner. The main strength of PENs is the diversity of competencies present. Police practitioners, civil society, and academia have the opportunity to jointly work towards identifying, exploring, and solving crucial police reform and assistance issues in a comprehensive manner. The different arenas and collaboration opportunities activated during the ICT4COP project period have provided important platforms for co-creating a solid knowledge base that can provide valuable insights to all stakeholders. This process is very much in line with the EU focus on co-creative processes in their re- 
search and innovation programmes, emphasising the need for cross-disciplinary, cross-sectorial, cross-institutional, and cross-border collaboration [91]. Furthermore, EU policies contend that dialogue and active cooperation between science and society help achieve socially responsible research and innovation processes that are also more relevant to citizens (European Union, 2014). European Union policies consequently advocate for co-creative approaches whereby researchers and societal stakeholders jointly develop new knowledge and solutions in various formats [91]. We argue that PENs can also play an important role.

While a PEN will not be able to address all of the challenges faced by international or national police reform missions, we believe that such a network has the potential to be an important positive resource for improving police reform projects. The 'HIPPO report' \# 256 recommend:

'Missions develop strategies for community engagement at various stages of the mission cycle, including assessment, analysis, planning, implementation, review and evaluation, and make increasing use of the resources of national staff in designing and implementing those strategies;'.

In the previous chapter (\# 255) the HIPPO commission state that 'Peace operations have some way to go to create strong channels of communication with local populations'. A group of PEN-members with participation from local police, previous peacekeepers, and representatives from local communities who can work together to improve the bottomup focus of police assistance in post-conflict societies while furthering the best interests of the local population, without having to accommodate outside national and international political agendas [91].

Police expert networks can serve as a discussion counterpart and advisory group for reform efforts. The aim of PENs is to support ongoing reforms or missions, not for PEN members to run or participate in police missions. Our idea is that a PEN can act as an additional bridge between donors' wish for a 'quick Fix and easy to document deliverable' and the host societies' wish for a 'renewed, reliable, accountable and democratic' future police service to be developed, performing in accordance with universal human rights standards. Ideally, the network membership will grow as police, civil society practitioners, and academics from countries undergoing reform join and share their challenges and experiences.

Development and reform of conflict-ridden societies has become a large 'international industry'. It is both understandable and rational for actors involved in the development of a service such as the police to concentrate on tasks that produce swift and documentable results, which can be reported back to donors and personnel-providing organisations. For example, it is easier to report the numbers of host officers trained than of changes in policing skills and behaviour. As Rathmell stated, 'The matter of institution building, however, has been largely ignored by observers and policy makers; it is often seen as a long-term issue that is too far removed from immediate security needs' [23]. A 'knowledge base' of information that can be utilised effectively in long-term bilateral and multilateral police reform and development is the ultimate goal of establishing a PEN. By becoming an established actor, a PEN will be in a position to counteract the trend of focusing on short-term goals by providing guidance and advice based on the PEN members' combined personal experience and knowledge.

There are often different international, national, local, and personal interests at play during a reform process, and these interests are not necessarily aligned or in the best interest of the local population. Reform mission leaders or local community leaders may not agree with the advice provided by a PEN. Given their volunteer and individual nature, PEN can provide input based on broad knowledge and experience to facilitate an open and transparent debate on how to advise on local police assistance and development. Police expert networks operate as independent groups and do not promote any other agenda than the best possible outcome for the host community to develop their police service.

In many post-conflict societies and societies facing ongoing conflict, the police as an organisation often struggles to define its own legitimacy separate from politics and the corrupt interests of the state and/or its elite-a situation often unfamiliar to international police advisors. Experienced PEN members in these contexts will have an understanding of local dynamics and may be able to suggest ways to support the police to work towards independence from corrupt practices in order to strengthen the legitimacy of the police within the society and become more effective.

\section{Acknowledgments}

We would like to thank the PEN members (researchers, practitioners and law enforcement professionals) whose valuable inputs, comments and feedback helped shape this paper. A special thanks to Ingrid Nyborg, Douglas Brand, A. Heather Coyne, Daniel Lohmann, Deniz Kozak, Kurt Eyre, Cecilia Dunster, Rifat Marmullaku and Yann-Cedric Quero who have provided critical insights to earlier versions of the paper. We would also like to extend our gratitude to the anonymous reviewers who provided constructive critical comments during the peer-review process. 


\section{References and Notes}

[1] The concept of post-conflict in this paper refers to countries where there have been high levels of violence and some degree of intervention, either in the form of national or international military or police missions, and that are undergoing some form of recovery and reform process (see the introductory editorial by Nyborg (this issue) for further discussion on post conflict contexts).

[2] After the 2017 UN Reform DPKO was divided into two separate departments: 'Department of Peace Operations' (DPO) and 'Department of Political and Peacebuilding Affairs' (DPPA). Available from: https://peacekeeping.un.org/sites/default/files/dppa-dpo-orgchart-2019.pdf.

[3] O'Neill WG. Police Reform in Post-Conflict Societies: What We Know and What We still Need to Know. New York, NY, USA: International Peace Academy New York; 2005. Available from: https: //www.ipinst.org/wp-content/uploads/publications/polreferpt.pdf.

[4] Peake G, Marenin O. Their Reports are not Read and their Recommendations are Resisted: The Challenge for the Global Police Policy Community. Police Practice and Research: An International Journal. 2008;9(1):59-69. doi:10.1080/15614260801969938.

[5] Mani R. Contextualizing Police Reform: Security, The Rule of Law and Post-conflict Peacebuilding. International Peacekeeping. 1999;6(4):9-26. doi:10.1080/13533319908413796.

[6] Bayley DH. Police Reform as Foreign Policy. Australian \& New Zealand Journal of Criminology. 2005;38(2):206-215. doi:10.1375/acri.38.2.206.

[7] Downes M. Police Reform in Serbia: Towards The Creation of a Modern and Accountable Police Service. Stockholm, SE: Organization for Security and Co-operation in Europe; 2004. Available from: https://www.osce.org/files/f/documents/7/a/18310.pdf.

[8] Ziegler M, Nield R. From Peace to Governance: Police Reform and the International Community. Washington Office on Latin America (WOLA); $2002 . \quad$ Available from: https://www.ojp.gov/ncjrs/virtual-library/abstracts/peacegovernance-police-reform-and-international-community.

[9] Bayley DH, Perito R, Perito R. The Police in War: Fighting Insurgency, Terrorism, and Violent Crime. Lynne Rienner Publishers Boulder; 2010.

[10] Marenin O. Restoring Policing Systems in Conflict Torn Nations: Process, Problems, Prospects. Geneva Centre for the Democratic Control Armed Forces; 2005.

[11] Nathan L. No Ownership, No Commitment: A Guide to Local Ownership of Security Sector Reform. 2007; Available from: https://issat.dcaf.ch/download/2210/19148/Nathan\%20No_ Ownership_No_Commitment.pdf.

[12] Donais T. Local Ownership and Security Sector Reform. In: Understanding Local Ownership in Security Sector Reform. Geneva Centre for Security Sector Governance (DCAF); 2008. pp. 3-18.

[13] Donais T. Inclusion or Exclusion? Local Ownership and Security Sector Reform. Studies in Social Justice. 2009;3(1):117-131. doi:10.26522/ssj.v3i1.1027.

[14] Ferguson C. Police Reform, Peacekeeping and SSR: The Need for Closer Synthesis. Journal of Security Sector Management. 2004;2(3):1-13.

[15] Easton M, Den Boer M, Janssens J, Moelker R, Vander Beken T. Blurring Military and Police Roles. Citeseer; 2010.

[16] Winkler TH. Managing Change: The Reform and Democratic Control of the Security Sector and International Order. 2002; Available from: https://dcaf.ch/sites/default/files/publications/documents/op01_ managing-change.pdf.

[17] Caparini M. Security Sector Reform in the Western Balkans. In: The Independent Resource on Global Security. 8. Stockholm International Peace Research Institute (SIPRI) Yearbook; 2004. pp. 251-282. Available from: https://www.sipri.org/sites/default/files/SIPRIYB0408.pdf.

[18] Bayley DH. Changing the Guard: Developing Democratic Police Abroad. Oxford University Press; 2005.

[19] Marenin O. Policing Change, Changing Police: International Perspectives. vol. 14. Taylor \& Francis; 1996.

[20] Holm TT, Eide EB. Peacebuilding and Police Reform. vol. 7. Psychology Press; 2000.

[21] Goldsmith A. Police Reform and the Problem of Trust. Theoretical criminology. 2005;9(4):443-470. doi:10.1177/1362480605057727.

[22] Pino N, Wiatrowski M. Democratic Policing in Transitional and Developing Countries. Routledge; 2006.

[23] Rathmell A, Oliker O, Kelly TK, Brannan D, Crane K. Developing Iraq's Security Sector:The Coalition Provinsional Authority's Experience. RAND National Defense Research Institute; 2005. doi:10.7249/mg365osd.

[24] Wilder AR. Cops or Robbers?: The Struggle to Reform the Afghan National Police. Kabul, AF: Afghanistan Research and Evaluation Unit Kabul; 2007. Available from: https://www.refworld.org/docid/ 47c3f3c60.html.

[25] Manning PK. Policing Contingencies. University of Chicago Press; 2010. doi:10.7208/chicago/9780226503523.001.0001.

[26] Bayley DH. Democratizing the Police Abroad: What to Do and How to Do It. vol. 3. US Department of Justice; 2001. Available from: https://www.ojp.gov/pdffiles1/nij/188742.pdf.

[27] The UN define Community Oriented Policing in the Manual for CoP in UN Peace Operations from 2018 as 'Community-Oriented Policing'; a strategy for encouraging the public to act as partners with the police in preventing and managing crime as well as other aspects of security and order based on the needs of the community. Available from: https://police.un.org/sites/default/files/manual-communityoriented-poliicing.pdf.

[28] Neild R. Themes and Debates in Public Security Reform: A Manual for Civil Society. Community Policing. Geneva Centre for Security Sector Governance: Washington Office on Latin America; 1998. Available from: https://www.wola.org/analysis/themes-and-debatesin-public-security-reform-a-manual-for-civil-society/.

[29] Edwards CJ. Changing Policing Theories for $21^{\text {st }}$ Century Societies. Federation Press Leichhardt, NSW; 1999. Available from: https://books.google.com/books?id=nflqKQEACAAJ.

[30] Goldsmith A. Policing Weak States: Citizen Safety and State Responsibility. Policing \& Society. 2002;13(1):3-21. doi:10.1080/1043946032000050553.

[31] Brodgen M, Nijhar P. Community Policing: National and International Approaches. Cullompton: Willan Publishing; 2005.

[32] Beck A. International and Regional Initiatives: Providing Appropriate International Assistance. 2000;

[33] Brogden M. Horses for Courses and Thin Blue Lines: Community Policing in Transitional Society. Police Quarterly. 2005;8(1):64-98. doi:10.1177/1098611104267328.

[34] Ellison G. Fostering a Dependency Culture: The Commodification of Community Policing in a Global Marketplace. Social Science Research Network (SSRN) Electronic Journal. 2007;doi:10.2139/ssrn.1816751.

[35] Kyed HM, Albrecht P. Handbook of International Security and Development. Edward Elgar Publishing; 2015. doi:10.4337/9781781955536.00025.

[36] Barão L. Addressing the Enforcement Gap to Counter Crime. World Bank; 2016. Available from: https: //openknowledge.worldbank.org/bitstream/handle/10986/24415/ Part02000optio0gagement0with0police.pdf?sequence $=1 \&$ isAllowed $=y$.

[37] Brundtland GH. World Commission on Environment and Development. Environmental Policy and Law. 1985;14(1):26-30. Available from: https://sustainabledevelopment.un.org/content/documents/ 5987our-common-future.pdf.

[38] Allen J, Ervin D. Introduction to Sustainability Concepts and Theories. Center for Sustainable Processes and Practices PSU Academic Sustainability Programs; 2007. Available from: https://docslide.us/documents/introduction-to-sustainabilityconcepts-and-theories-jennifer-allen-and-david.html.

[39] Basiago AD. Economic, Social, and Environmental Sustainability in Development Theory and Urban Planning Practice. Environmentalist. 1998;19(2):145-161. doi:10.1023/A:1006697118620.

[40] Bajraktari Y, Boutellis A, Gunja F, Harris DY, Kapsis J, Kaye E, et al. The PRIME System: Measuring the Success of Post-conflict Police Reform. Princeton University. 2006; Available from: http: //www.dmeforpeace.org/sites/default/files/Princeton\%20University_ $\% 20$ The\%20Prime\%20System\%20Measuring\%20the\% 20Success\%20of\%20Post\%20Conflict\%20Police\%20Reform.pdf.

[41] Narotzky S, Besnier N. Crisis, Value, and Hope: Rethinking the 
Economy: An Introduction to Supplement 9. Current Anthropology. 2014;55(S9):S4-S16. doi:10.1086/676327.

[42] Scheye E. Unknotting Local Ownership Redux: Bringing Nonstate/Local Justice Networks Back in. In: Donias T, editor. Local Ownership and Security Sector Reform; 2008. pp. 59-81. Available from: https://www.dcaf.ch/sites/default/files/publications/documents/ LocalOwnershipandSSR1.pdf.

[43] Mani R. Police Reform Concept Paper for Whitehall Policy Seminar. vol. 9; 2003. Available from: http://www.ssronline.org/edocs/manir_ policing_in post-conflict_2003.pdf.

[44] Rathmell A. Fixing Iraq's Internal Security Forces: Why is Reform of the Ministry of Interior so Hard? United States Institute of Peace; 2007. Available from: https://www.jstor.org/stable/resrep12291.

[45] Divona SA. Police Reform and Power in Post Conflict Societies. European Journal of policing Studies. 2017;4(3):267. Available from: https: //nmbu.brage.unit.no/nmbu-xmlui/bitstream/handle/11250/2490053/ Divon_police\%2breform_2016.pdf?sequence=1\&isAllowed=y.

[46] Evans R. Donor Perspective on Security Sector Reform as a Governance Issue. $5^{\text {th }}$ International Security Forum in Zurich; 2002. Available from: https://issat.dcaf.ch/download/3108/26492/Donor\% 20Perspective\%20on\%20SSR\%20as\%20a\%20Governance\% 20Issue\%20-\%20Evans\%20(2002).pdf.

[47] Marenin O. Understanding Mission Environments: Local Contexts and the Legitimation of Reforms. Journal of International Peacekeeping. 2010;14(3-4):223-247. doi:10.1163/187541110X504337.

[48] Alkire S. A Conceptual Framework for Human Security [Working paper]. Oxford, UK: Centre for Research on Inequality, Human Security and Ethnicity (CRISE), Queen Elizabeth House, University of Oxford; 2002. Available from: https://citeseerx.ist.psu.edu/viewdoc/ download?doi=10.1.1.580.2805\&rep=rep1\&type=pdf

[49] Tadjbakhsh S, Chenoy A. Human Security: Concepts and Implications. vol. 51. Routledge; 2007.

[50] Nyborg I. Emerging Perspectives on Post-Conflict PoliceCommunity Relations. Journal of Human Security. 2019 may;15(2). doi:10.12924/johs2019.15020001.

[51] Wisler D, Onwudiwe ID. Community Policing: International Patterns and Comparative Perspectives. CRC Press; 2009.

[52] Greener BK. UNPOL: UN police as peacekeepers. Policing \& Society. 2009;19(2):106-118.

[53] Light Blue: Public Perceptions of Security and Police Performance in Kosovo. United Nations Development Programme (UNDP); 2004. Available from: https://www.scribd.com/document/165071119/LIGHTBLUE-Public-Perceptions-of-Security-and-Police-Performance-inKosovo.

[54] Albrecht P, Jackson P. Security System Transformation in Sierra Leone, 1997-2007. Birmingham, UK: Global Facilitation Network for Security Sector Reform (GFN-SSR); 2009.

[55] Patten C. A New Beginning: Policing in Northern Ireland. Norwich, UK: Independent Commission on Policing for Northern Ireland; 1999. Available from: https://cain.ulster.ac.uk/issues/police/patten/patten99. pdf.

[56] Jackson P. Handbook of International Security and Development. Edward Elgar Publishing; 2015.

[57] Nyborg I, Ganapathy J. Introducing the Issues: Human Security, Development and the Civil Police in Afghanistan [Workshop Report for 'The Norwegian Police Engagement in Afghanistan: Perspectives on security and development for local women and men']. Oslo, Norway: The House of Literature; 2012.

[58] Hänggi $H$. Approaching Peacebuilding from a Security Governance Perspective. In: Bryden A, Hänggi H, editors. Security Governance in Post-conflict Peacebuilding. Münster and New Brunswick, NJ: Lit Verlag and Transaction Publishers; 2005. pp. 3-22.

[59] Holmqvist C. Engaging Armed Non-state Actors in Post-conflict Settings. In: Security Governance in Post-Conflict Peacebuilding. Geneva Centre for the Democratic Control of Armed Forces; 2005. pp. 45-68.

[60] Harris F. The Role of Capacity-building in Police Reform. Organization for Security and Co-operation in Europe (OSCE), Mission in Kosovo; 2005. Available from: https://www.osce.org/files/f/documents/7/f/ 19789.pdf.

[61] Ashraf MA. The Lessons of Policing in Iraq a Personal Perspective. Policing: A Journal of Policy and Practice. 2007;1(1):102-110. doi:10.1093/police/pam008.

[62] Moss M. How Iraq Police Reform Became Casualty of War. The New York Times. May 22; Available from: http://www.nytimes.com/2006/ 05/22/world/middleeast/22security.html?mcubz=1.

[63] Celador GC. Police Reform: Peacebuilding through 'Democratic Policing'? International Peacekeeping. 2005;12(3):364-376. doi:10.1080/13533310500074184.

[64] Call CT. Challenges in Police Reform: Promoting Effectiveness and Accountability. International Peace Academy. 2003; Available from: https://www.ipinst.org/wp-content/uploads/publications/ challenges_in_police.pdf.

[65] Pfaff T. Development and Reform of the Iraqi Police Forces. 2008; Available from: https://publications.armywarcollege.edu/pubs/1935. pdf.

[66] Cooper N, Pugh M. Security-sector Transformation in Post-conflict Societies. Conflict, Security \& Development Group, King's College London; 2002. Available from: https://gsdrc.org/docs/open/SSAJ150.pdf.

[67] Hansen S. One Size Fits All? Adjusting Policing to Local Circumstance. Policy Brief. The ICTCOP4 Magazine;Policy Brief 7. Available from: https://www.communitypolicing.eu/resources/policybriefs/index.html.

[68] Bahadar N, Dawar S, Nyborg I, Maqsood T. Community-Oriented Policing: Political, Institutional and Technical Reforms in Khyber Pakhtunkhwa (KP) Police. Journal of Human Security. 2019;15(2):4153. doi:10.12924/johs2019.15020041.

[69] Nyborg I, Ganapathy J, Nimruzi A. From Guns to Roses: Understanding Community-Oriented Policing in Afghanistan. Journal of Human Security. 2019:15(2). doi:10.12924/johs2019.15020054.

[70] Peake GP. Policing the Peace: Police Reform Experiences in Kosovo Southern Serbia and Macedonia. Saferworld; 2004. Available from: http://www.saferworld.org.uk/downloads/pubdocs/Policing\% 20PA2.pdf.

[71] Diehl PF, Balas A. Peace Operations. War and Conflict in the Modern World. Wiley; 2014.

[72] Numbers from "ZIF Peace Map 2019-2020". Available from: https://www.zif-berlin.org/sites/zif-berlin.org/files/inline-files/ ZIF_World_Map_Peace_Operations_2019_2.pdf.

[73] Tjønneland EN, Wimpelmann T, Paterson A, Albertyn C, Fleming D, Hills A. Building Blocks for Peace An Evaluation of the Training for Peace in Africa Programme. Evaluation Department, Norad; 2014. Available from: https://www.cmi.no/publications/5287-buildingblocks-for-peace-an-evaluation-of-the\#pdf.

[74] The case countries in the ICT4COP project are Afghanistan, Pakistan, Kenya, Somalia, Uganda, Nicaragua, Guatemala, El Salvador, Bosnia and Herzegovina, Serbia and Kosovo.

[75] Kocak D. Impunity: Countering Illicit Power in War and Transition. In: Hughes M, Miklaucic M, editors. Security Sector Reconstruction in Post-Conflict: The Lessons from Timor-Leste. Washington, DC, USA National Defense University; 2013. pp. 348-365. Available from: https://cco.ndu.edu/Portals/96/Documents/books/Impunity/CHAP 16\%20Security\%20Sector\%20Reconstruction.pdf?ver=2017-0119-102817-977".

[76] Workshops conducted by Norwegian Police University College, first March 2018 in Oslo, Oxford and Dublin in April 2019, Sarajevo September 2019, planned workshops in Pakistan and Kenya March 2020 cancelled due to the Covid-19 pandemic.

[77] Established in 2011.

[78] The call for funding from ICT4COP Consortium to EC Horizon 2020, p. 12.

[79] (see, Bourdieu, 1977; Foucault, 1984; Danilesen, 2008; Eriksen \& Scober, 2017;)

[80] Urstad B. Keeping a Diverse Workforce: More than Glossy Rhetorics. Scandinavian Journal of Organizational Psychology. 2012;4:23-31.

[81] Follett MP. Creative Experience. Longmans, Green and Company; 1924.

[82] Eriksen TH, Schober E, editors. Knowledge and Power in an Overheated World. University of Oslo; 2017.

[83] The original plan was to hold four final regional dissemination workshops before the project ended. However, due to the COVID outbreak in March, two regional dissemination workshops in Nicaragua and Kenya had to be cancelled.

[84] Lohmann D. ICT4COP Pakistan Regional Dissemination Report; 
2020. One-day Conference, and a one-day Workshop on March 10th and 11 th respectively, both held in Islamabad, Pakistan.

[85] Reported to author by the PEN-member in question.

[86] Rodriguez, A.M. (2020): Notes from Guatemala webinar.

[87] Feedback from a PEN member, 2018.

[88] Francia G. The Advance of Anti-gender Agenda in Swedish Media Debate on Higher Education. In: Re-thinking Knowledge Regimes-Solidarities and Contestations Swedish Secretariat for Gender Research Gothenburg, 7-9 October 2019; 2019. Available from: http://hig.diva-portal.org/smash/record.jsf?pid=diva2\% 3A1381763\&dswid=-2992.
[89] Osland K, Caparini M. Learning from Experience-International Policing. SSRN Electronic Journal. 2017; doi:10.2139/ssrn.2998680.

[90] Scheye E. Unknotting Local Ownership Redux: Bringing Non-state/local Justice Networks Back In. Local ownership and security sector reform. 2008;pp. 59-81. Available from: https://www.dcaf.ch/sites/default/files/publications/documents/ LocalOwnershipandSSR1.pdf.

[91] Lindberg M, Hallencreutz D, Tengqvist A. Bridging Participatory Policy Trends and Research Traditions through Social Innovation. Technology Innovation Management Review. 2019;9:27-36. doi:10.22215/timreview/1231. 